We thank Dr. G. F. Marrian and Dr. R. J. C. Harris for their encouragement and interest, and the Leverhulme Trust for continued support.

T. M. BeLL* M. G. R. Ross $\dagger$

Imperial Cancer Research Fund, P.O. Box 193

Entebbe, Uganda.

* Leverhulme Trust Research Fellow.

+ Leverhulme Trust Research Assistant.

${ }^{1}$ Bernhard, W., and Tournier, P., Ann. Inst. Pasteur, 107, 447 (1964)

2 Epstein, M. A., Achong, B. G., and Barr, T. M., Lancet, i, 702 (1964).

${ }^{3}$ Stewart, S. E., Lovelace, E., Whang, J. J., and Ngu, V. A., J. Nat. Cancer Inst., 34, 319 (1965).

4 Ginsberg, H. S., Fed. Proe., 16, 414 (1957)

${ }^{5}$ Walker, D. L., and Hinze, H. C., J. Exp. Med.,116, 739 (1962).

${ }^{6}$ Ishida, N., Homma, M., Osato, T., Hinuma, Y., and Miyamoto, T.' Virology, 24, 670 (1964).

Fernandes, M. V., Wiktor, T. J., and Koprowsky, H., J. Exp. Med., 120 1099 (1964)

${ }^{8}$ Henle, G., Hinze, H. C., and Henle, W., J. Nat. Cancer Inst., 31, 125 (1963).

' Hare, J. D., Balduzzi, P., and Morgan, H. R., J. Nat. Cancer' Inst., 30, 45 (1963).

in Rubin, H., and Temin, M., Fed. Proe., 17, 994 (1958).

${ }^{11}$ Wheelock, E. F., and Tamm, I., Virology, 8, 532 (1959).

${ }^{12}$ Roizman, B., and Schluederberg, A. E., Proc. Soe. Exp. Biol. and Med., 106, 320 (1961).

${ }^{13}$ Spendlove, R. S., Lennette, E. H., and John, A. C., J. Immunol., 90, 554 (1963).

${ }^{4}$ Bell, T. M., Massie, A., Ross, M. G. R., Simpson, D. I. H., and Griffin, L. (in the press).

${ }^{15}$ Burkitt, D., Hutt, M. S. R., and Wright, D. H., Cancer, 18, 399 (1965).

\section{Occurrence of a Specific Foetal Protein in a Primary Liver Carcinoma}

A particular protein component has been demonstrated in the blood serum of human foetuses and has been localized between albumin and alpha $a_{1}$-globulin by paper electrophoresis ${ }^{1,2}$. Using immunoelectrophoresis, with a specific rabbit serum immune against human foetal serum proteins, de Muralt and Roulet ${ }^{3}$ and one of us (J. M. $)^{4}$ found a specific precipitation line in the immunoelectrophoresis pattern of human foetal serum corresponding to an alpha $a_{1}$-globulin. According to de Muralt and Roulet ${ }^{3}$, this specific foetal alpha $a_{1}$-globulin disappears from the serum of foetuses after the twentieth week of intrauterine life. But it has been possible to demonstrate the presence of this protein in the serum of older foetuses, and in the cord blood serum as well as in that of nowborns in the first week after birth ${ }^{5}$. These findings probably confirm the existence of a protein which is characteristic of the foetal period in man and which is called "foetoprotein" 3,4 . This protein has not yet been found in the serum of normal individuals later than the first two weeks of postnatal life.

In two cases of primary carcinoma of liver, Tatarinov ${ }^{6,7}$ found a protein which he detected also in blood serum of human foetuses and which he called "embryo-specific alpha-globulin".

Immunoelectrophoresis was carried out with the blood serum of our patient, a 14 year old boy, with primary carcinoma of the liver (as confirmed by laparotomy and biopsy) using the specific rabbit serum immune against human foetal serum proteins which had been absorbed with pooled sera of normal children 10-15 years of age. A precipitation line corresponding to an alpha $a_{1}$-globulin component was present in the immunoelectrophoresis pattern of the serum of the patient and the protein was found to be immunologically identical with that of foetoprotein (Fig. 1). The concentration of this component was found by means of quantitative linear immunodiffusion to increase with the progress of the illness, from approximately $20 \mathrm{mg}$ of foetoprotein per $100 \mathrm{ml}$. of serum in May to $90 \mathrm{mg}$ per $100 \mathrm{ml}$. in September. The

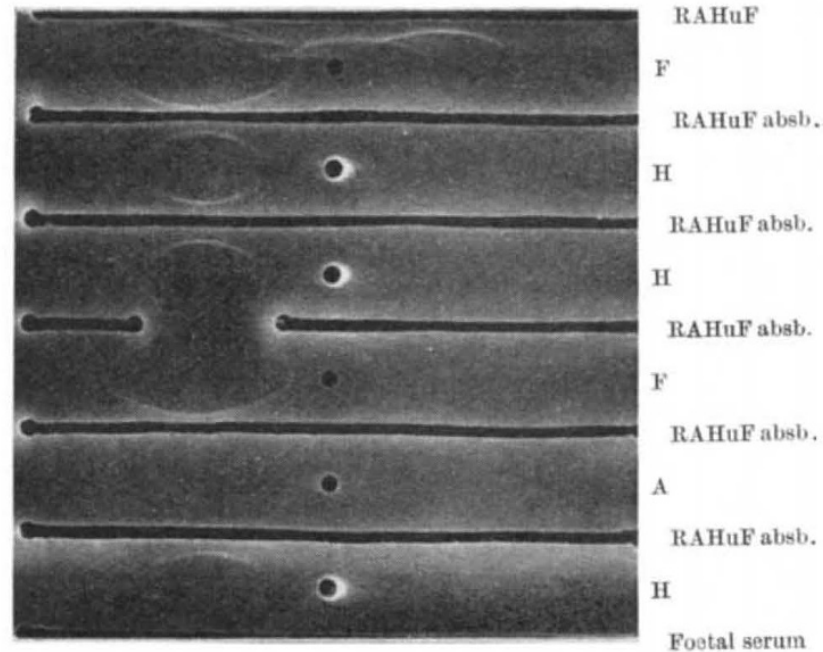

Fig. 1. Immunoelectrophoretic pattern of the serum of the patient $(\mathrm{H})$ compared with that of a normal adult (A) and a human foetus (F). On the longitudinal baseline a rabbit serum immune against human foetal gerum proteins (RAHuF) and the same immune serum absorbed with serum proteins (RAHuF) and the same immune serum absorbed with a normal human serum (RA with the precipitation line of the foetoprotein in the human foetal serum (third sample).

foetoprotein was also found to be present in the ascitic fluid of the patient, in extracts of the stool and in the urine which had been concentrated 500 times.

\section{K. Kithier \\ J. Houšrť̌k \\ J. Masopust \\ J. RÁDI}

Research Institute of Child Development,

Faculty of Paediatries,

Charles University,

Prague.

${ }^{1}$ Bergstrand, C. G., and Czar, B., Scand. J. Clin. Lab. Invest., 8, 174 (1956). 'Halbrecht, J., and Klibanski, C., Nature, 178, 794 (1956).

${ }^{3}$ de Muralt, G., and Roulet, L. D. A., Helv, Paediat. Acta, 16, 517 (1961).

4 Masopust, J., Rev, Czech. Med, 8, 214 (1962).

${ }^{5}$ Masopust, J., and Kotál, L., Ann. Paediat., 204, 138 (1965).

- Tatarinov, Y. S., Vopr. Med. Chimii, 10, 90 (1964).

Tatarinov, Y. S., Vopr. Med. Chimii, 11, 20 (1965).

\section{Pulmonary Tumours in Rats induced by Oral Hydrazine Sulphate}

RATs provide good material for the study of pulmonary carcinogens since spontaneous pulmonary tumours are very rare. They have never been observed in colonies maintained by Orr and Bielschowsky ${ }^{1}$ or by Mori ${ }^{2}$, and when Wilson et al. ${ }^{3}$ killed about 1,500 rats and carried out histological examinations on all the organs suspected of neoplasia, they did not observe pulmonary tumours.

Biancifiori and Ribacchi ${ }^{4}$ and Biancifiori et al. ${ }^{5}$ showed that hydrazine, the principal metabolite of isoniazid, induces pulmonary tumours in susceptible and resistant mice. In this experiment, hydrazine sulphate was administered to $C B R I / S e$ rats to investigate whether this chemical was carcinogenic. Eighty-two rats of both sexes were used, 50 controls and 32 rats troated from the age of 8 weeks with hydrazine sulphate in aqueous solution through a stomach tube for about 68 weeks. A different daily dose was given to males and females. because the average weight of these animals, at about 12 weeks of age, was about 250 and $350 \mathrm{~g}$, respectively.

The treatment was interrupted by rest periods, and a total of 215 doses was given. The chemical was pure and supplied by Farmitalia, Milan. The incidence of pulmonary tumours is shown in Table 1 . Of the 32 rats which received hydrazine sulphate, 8 (25 per cent), 